Schizoid Femininities and Interstitial Spaces:

Childhood and Gender in Celine Sciamma's Tomboy and P.J. Hogan's Peter Pan

\begin{abstract}
Childhood innocence has often been treated by scholars as an empty, idealised signifier. This article contests such accounts, arguing that innocence is best regarded as a powerfully unmarked training in heternormativity, alongside class and race norms. This claim will be demonstrated through attention to two recent films addressing childhood: Celine Sciamma's Tomboy and P.J. Hogan's Peter Pan. The films characterise young femininity as an 'impossible space', in which subjects face the contradictory, schizoid demands to simultaneously show both childhood innocence and heteronormative femininity - or else face the threat of a spoiled identity. The plot of each film traces how the protagonist attempts to manoeuvre in the face of and precisely using this contradiction. In dramatising such manoeuvring, the films reveal the surprising forms of subjectivity (e.g. the tomboy) which can be inhabited for a time in the interstices between age and gender norms, and which might have lasting value. Both films thus dramatise how an interstitial space can offer possibilities for negotiating the terms under which a subject is inserted into dominant, recognisable forms of subjectivity.
\end{abstract}

\title{
Introduction
}

In Cinema's Missing Children, Wilson (2003: 2) examines films that address how adults manage experiences and fantasies of loss as figured through the image of an innocent child. Her rich analyses reveal something surprising: 'the missing child is, in such contemporary film, more properly a vanishing point, an absence around which the narrative is elaborated'. 'The issue of the missing child', Wilson suggests, 'enables films to mobilise questions about the protection and innocence of childhood, about parenthood and the family, about the past and about the future' (ibid. 158). Celine Sciamma's Tomboy and P.J. Hogan's Peter Pan, unlike the films considered by Wilson, follow the child who goes missing. They turn attention away from adult narratives of innocence and loss, and toward the manner in which innocence discourses open and close possibilities for subjects. Specifically, the absence around which the narrative is elaborated in both films is the gap that opens up, whilst the child is away from the familial social structures that might otherwise occlude it, between the 'girl' and her femininity. 
In Tomboy, the ten-year-old protagonist Laure (played by Zoé Héran) presents as a tomboy with the tacit acceptance of her mother and the affirmation of her father. She is taken to be a boy by a neighbour, Lisa, and selects the name 'Mickäel'. Each day, over the summer holidays, Laure disappears from her parents into the nearby woods where Mickäel has adventures. In contrast to the paths that might have been available as Laure, Mickäel is accepted in the football games of the local boys; he is invited into a romantic relationship with Lisa; and he plays counterpoint to younger sister Jeanne's aspirations to heteronormative femininity. Tomboy traces the 'tomboy' as a form of subjectivity that raids some of the signifiers of dominant masculinity. Yet it also makes visible the way in which the tomboy subjectivity is made acceptable, for a limited time, precisely by the tension between imperatives on young females to be prior to sexuality yet ultimately heterosexual.

Peter Pan tells of liminality and childhood innocence in a normative, Hollywood vein: it positively valorises heternormativity, though with some wistfulness. However, on the way to this accomplishment, the film evidences a parallel set of tensions to Tomboy. In this regard it continues a tradition 'that, as a cultural myth', each retelling of Peter Pan tends to 'offer the tools for its own undoing, as it goes' (Rose 1992: xii). Hogan's film dresses up as the classic story in order to tell a new tale about heterosexual desire. In doing so, it puts into relief both the differences and continuities between the Edwardian gender norms of the Darling household and contemporary ones of Neverland. Going missing to Neverland with Peter helps Wendy in turn escape, weigh up, and then navigate the gendered expectations on her; in this way she negotiates her acceptance of a heteronormative future.

In a previous article, I offered an analysis of discourses of childhood innocence, and their role in the subjectivation of young women. Innocence appears to be the mere expression of a neutral and universal essence attached to childhood. However, through an analysis of Frank Wedekind's Mine-Haha, I showed innocence to be both a covert and normalising training in cultural acceptability, and an ideal differentially allocated between young subjects. Innocence discourses permit a 'natural essence' to be performatively constructed, without this seeming to be an artificial imposition, by classifying some of the practical means through which it is socially and materially constructed as inessential. Innocence can thereby seem to be the happy but threatened 
result of an expression of originary and homogenous essence, extracting social norms from history and from politics. Kincaid (1992: 175) suggests that 'hollowing out of children by way of purifying them of any stains (or any substance) also makes them radically different, other. In this empty state, they present themselves as candidates for being filled with, among other things, desire. The asexual child is not... any the less erotic but rather more.' My analysis leads to a quite different conclusion, given that normative childhood is not just any 'other' but a specific cultural, material and affective construction: innocence only appears as blankness, but is in fact a powerfully unmarked training in heternormativity, alongside class and race norms.

I shall advance these considerations further here through an examination of Tomboy and Peter Pan, attending more precisely to the operation of gender norms in the biographical movement in-between and away from presumed innocence. Whereas in previous work, I have tended to treat age and gender norms as generally supporting one another, here I look for the social and affective implications of their disjunctures drawing together reflections from both the social sciences and humanities. For Tomboy and Peter Pan do not only evidence gender as a performative accomplishment, made out of the discourses which appear to merely name it. They show how, for young women, this performative activity must creatively and awkwardly dance upon a contemporary terrain riven by constitutive tensions between innocence and compulsory heterosexuality. This terrain opens up certain choices as sufficiently acceptable, so long as essentialised identity-categories are not denaturalised.

\section{Schizoid Femininities}

'Tomboy' literary figures and social subjectivities, Thorne suggests, 'have been created in different decades, and they span varied regions and specific concerns. But they all tap into, and have helped construct, a persistent cultural figure' who 'chafe[s] at the restrictions of imposed femininity'. Tomboys are 'adventuresome, they like to move freely and be outdoors. They dislike dresses and feminine adornments, and they are drawn to activities associated with boys.' Thorne observes, however, that the tomboy character is enveloped by narratives in which make-believe is ultimately punctured by the reality of sexual difference. Like a Shakespearean comedy, the gender play necessarily comes to an end in the tomboy narrative: 'the stories always conclude with 
the girl's entry into adolescence and young womanhood... they keep some of their spirit and independence, but they become softened, both more affirming of, and reconciled to, definitions of their gender that they had previously opposed'. For a short time, 'the tomboy sets herself apart from others of her gender, becoming an exception to a group that is otherwise disparaged'. For this reason, Thorne (1993: 113) expresses concern regarding the 'tomboy' figure, which 'may protest against, but also helps perpetuate, gender stereotypes'. However, writing in the 1990s, she suggests that the term may be in the process of disappearing: 'Kids' use of the term may have been undermined by changes in the past two decades, such as challenges of gender stereotypes, more acceptance of girls in team sports, loosened dress codes, and a general lessening of pressure on girls to be 'ladylike" (ibid. 115; see also Reay 2001).

Yet an alternate account has been offered by Renold, following in her analysis of the subject-position of the 'girl'. In a powerful and incisive analysis, Renold discerns a pressure on women to achieve an ideal of free, self-possessed desirability - 'compulsory heterosexuality' - to which women need to aspire for their gender performance to be understood as acceptable. This compulsory heterosexuality, however, intersects with age norms that hold that children, and especially female children, should maintain a sexual innocence. For though children are often 'presumed innocent', Renold's (2002: 429) fieldwork in British primary schools has shown that 'heterosexuality is part and parcel of their gender identity constructions'. Renold (2008: 130) suggests that, increasingly in contemporary society, 'girls can invest in culturally "diverse" femininities (thus exercising choice) so long as they project coherent intelligible heterosexualised femininities (upholding the logic of sameness). The pushes and pulls of the simultaneous demand for compulsory innocence and compulsory heterosexuality and the diversification and fixing of class/race/gender/age norms, is a dynamic which I refer to... as "schizoid femininities".'

With her use of the term 'schizoid', Renold is calling attention to the way in which young women are enjoined to 'just be themselves' within a frame generated by gender and age norms. As a result, the available forms of subjectivity ever risk appearing improper by one standard or another, and also that this incoherence appears to reflect a flaw in the individual's personality and choices rather than a response to paradoxical cultural demands. The material and cultural resources to reconcile these tensions and achieve 
an acceptable gender performance are distributed by class, race and age. Yet in her work with Ringrose, Renold has analysed how the punitive gender norms and the differential allocation of resources for satisfying them are hidden by a moralising focus on young women themselves as sexual choice-makers (Renold \& Ringrose 2011; Ringrose \& Renold 2012; cf. Hay 2009). Young women, Renold and Ringrose argue, are held responsible for displaying an aspirant and unmarked heterosexual identity, whilst simultaneously not allowing this display to be sufficiently visible as to be read as 'too slutty'. There are few intelligible or acceptable ways to be understood as a proper 'girl' that do not attempt this walk-of-the-tightrope, which retains the position of women as the gatekeepers of reproductive sexuality.

Against Thorne's prediction of its demise in a more gender tolerant society, Renold (2009: 231) identifies that the tomboy performance is not simply still relevant in such circumstances, but has a particular appeal in serving to 'deflect sexualized comments and harassment' which have increased along with the pressure on both young men and women to use sexual signifiers to assert a valued gender identity (see also Chambers et al. 2004; Ringrose et al. 2012). This matches other research (e.g. Morgan 1998) which notes an increasing number of tomboys over generations, and a declining age at which the tomboy performance is halted as a result of sexual and gender bullying from peers.

Attending to schizoid femininities helps Renold trace the logic of 'tomboy' discourses, as well as their embodiment in 'tomboy' subjectivities. Her ethnographic research shows how 'tomboy' discourse can be deployed as a frame of intelligibility for those subjects who try to deflect the pressure to enact heterosexualised femininities. Renold (2008: 137) describes how 'a persistent theme in being a "bit tomboy" in the girls' accounts were girls who were (for that day, or that week) "not girlie," that is not investing in heterosexualised hyper-femininity'. However, where British girls were middle-class and academically successful, 'tomboy' discourse was not necessary to make intelligible their distinction from hyper-femininity, since they could be abjected as 'square-girls' for over-investing in the subject-position of academic knower (Renold 2001; Renold \& Allan 2006).

\section{Sciamma's Tomboy}


Sciamma's Tomboy speaks of our contemporary moment as one in which the tomboy subjectivity continues to appeal. In doing so it points to the way in which social changes have altered but not, as Thorne predicted, removed the inequalities and forms of exclusion associated with normative femininities. Discussing her film in interview, Sciamma draws out the way in which children are under certain intensified pressures to achieve a normative gender identity. This shift, she suggests, does not negate the fact that contemporary culture is more permissive regarding the possibilities for subjectivity; like Renold, she thinks that these two tendencies, though superficially appearing opposed, exist simultaneously and in conjunction. Discussing children's clothing, for example, Sciamma notes that 'When you go to the department stores you look at kid's clothes, I mean in France, I don't know how it is in the U.S., trying to find a tshirt for a girl that is navy blue or red without something written on it that says 'girly' or flowers, it's just impossible.' She agrees with the interviewer that heterosexuality is increasingly suggested or imposed as a norm for young people, and adds that important in the operation of these norms has been the ascendance of childhood as a marketing category:

Sciamma: Everybody says it's a more permissive time-of course it is-but on the gender pressure-I feel like it's so much more than when I was a kid.

Interviewer: And you think that's because childhood is so much shorter and because it's about rushing to get to adulthood and sexuality?

Sciamma: I think childhood is also a marketing target now' (Sciamma 2011).

This contemporary situation is addressed by Tomboy as refracted through the psychosocial dynamics of Laure's family. Following the title, flashing in blue and pink, we see Laure on her father's lap, holding the steering-wheel of the car with him as they transport their possessions to a new home. The father is played by Mathieu Demy, among the most famous 'sons' of French film: the child of directors Agnès Varda and Jacques Demy, he frequently played the son of this or that character in their works through the late 1980s and early 1990s. Laure and her father take pleasure in driving together, enacting child's identification with a father who in turn is coded to the viewer as an outgrown 'son'. Later, playing the card-game Happy Families, the father states 'I 
want the Son'; it's a card that Laure is not able to supply. The father then offers Laure a try of his beer.

In Laure's first conversation with her mother, putting his head down gently on top of her pregnant midriff, gender norms are also at stake. 'My room is lovely', says Laure, laying her head down gently on top of her mother's pregnant stomach. 'Did you see the blue walls? Just the way you wanted' the mother replies. A terrain has been established in which Laure's performance of 'tomboy' is permissible; this permissibility, however, operates within a commitment to the binary of sexual difference. Laure is permitted signifiers from the masculine side of this divide, but is interpellated as female: she can wear tightly cropped hair and a sleeveless shirt, and younger sister Jeanne can wear her long hair in bunches and wears a pink tutu, yet both together are referred to as 'the girls'.

Yet the permissibility of a tomboy performance within the home for Laure opens the possibility that they can be taken as signifiers of sexual identity. Laure sees a group of neighbourhood boys from the apartment window, and ventures out to look for them. 'They already left', explains Lisa, who is sitting on the steps to her apartment block. Lisa gives her name, expecting a reply, but none comes. 'Won't you tell me your name?', she asks. A pause, a look away, then a momentary half-smile: 'Mickäel. My name is Mickäel'. Lisa and Mickäel head together into the woods, and find the boys in a clearing. Lisa engineers that the two of them can join in a game of tag, one on each team. She deliberately loses to Mickäel 'so that your team will like you', a strategy that succeeds as Mickäel is applauded as 'cool' by his teammates.

Lisa facilitates Mickäel's movement to insider status, but is not able to follow. Lisa's position as a girl grants her no more than a dominated status within the group, despite the fact that social seniority is otherwise distributed by age. 'You're not the one in charge!' she is told. Perhaps this position can be linked to Lisa's willingness to lose the game of tag: she is already excluded from competing social dominance by virtue of her gender. She is excluded from the boys' games of football, which has the role of a protected site for the performance of and competition for hegemonic masculinity. Lisa explains to Mickäel: 'I don't have a choice. They don't want me to play. They say I'm useless'. Her designated role in the game of football is to 'play the cheerleader'. The 
cheerleader serves the function of audience for the performance of masculinity. The role of cheerleader generates a limited degree of agency, in that the cheerleader can assess and select for desirability so long as she does so within the criteria that organise hegemonic masculinity (cf. Renold 1997; Bettis \& Adams 2006). Initially Mickäel stays with Lisa on the sidelines of the football game. Leaning against a wall, Lisa stares at Mickäel appraisingly. 'You're not like the others', she notes, smiling, with her hands held in front of her. Mickäel, precisely because this compliment is worryingly true, does not respond. In the next game of football, however, he joins in, playing shirtless. Lisa calls him over, and offers him water. Looking at his body rather than his face, she notes 'you're good'. This combination of being 'not like the others', yet able to access the aspirant hegemonic masculinity of the successful football player, makes Mickäel an attractive prospect as a romantic partner for Lisa.

A further opportunity is also opened for Mickäel that would not have been open to the same extent to Laure: to support Jeanne further in her own identity-work. As Mitchell has proposed, the sibling relationship asks the question 'who am I?' of the subject, to which a key response is differentiation by the manner of gender performance. This differs, Mitchell (2003) suggests, from the child's relationship with parents who, on behalf of society's norms, categorise and differentiate children by reproductive sex. Jeanne takes every opportunity to perform aspirant heteronormative femininity. In part this may be linked to the cultural pressures considered by Renold; Jeanne is the only character ever seen watching television. However, such cultural pressures can be understood as refracted through Jeanne's identification with her mother, in the context of the threat represented by the potential for a new sibling. Jeanne states early in the film, with a big smile, that she hopes her mother's pregnancy ends in a miscarriage.

Jeanne's aspirant femininity makes continual use of her sibling. She dances in her tutu and matching flowered hairband, practicing lithe and graceful female embodiment in amusingly exaggerated motions, as Laure plays a toy piano. When Jeanne discovers that her sibling has been passing as a boy, she threatens that she will tell their mother. However, she clearly cares for her sibling and, moreover, is bribed with the chance to come along to play with the neighbourhood group. For Mickäel, as an older brother, is able to play an even more effective counterpoint to Jeanne's emphasised femininity than the tomboy performance of Laure. 'I have a big brother, which is better', she says, 
'because a big brother can protect you'. She relates how 'once, my brother fought some boys that were bullying me. He punched them really hard' and 'everyone was scared of him, and all the girls loved him. But he didn't care about anyone else but me'.

Mickäel does indeed go on to get into a fight with someone who pushed Jeanne, leading their mother to find out about his gender performance. Insisting that Laure wear a dress, her mother gently but firmly explains that 'I don't mind you playing "the boy". It doesn't even make me sad', but that 'we have no choice' since 'school starts in two weeks' time'. Thus, as Thorne predicts, the performance of masculinity comes to an end for the tomboy, who is exiled back to a disavowed subject-position. Yet Tomboy suggests the meaning of the tomboy performance is not simply the internalisation of sexist cultural norms and then the eventual acceptance of belonging to the subordinated group. The film dramatises the transitory inhabitation of an interstice within gender and age which mobilises gender norms precisely in order to reach for valuable opportunities and protections from exclusion.

Commenting on Tomboy, Dargis (2011) has suggested that the title of the film 'suggests that the child is a girl, one who dresses in plain shirts, shorts and sneakers without a touch of pink or a Hello Kitty backpack.' If, against Thorne's prediction of gender equalisation, femininity continues to mean narratives of feminine helplessness and the 'consumption femininity' of Hello Kitty backpacks then tomboy performance might be regarded as one strategy to avoid the available repertoire of femininity, achieved with the limited resources available to a ten-year-old. The top is cut off Laure's bathing suit with safety scissors, Mickäel's muscles are appraised in the bathroom mirror, and a phallus is crafted out green play-dough to produce a bulge in his swimwear. What makes the tomboy strategy complex for feminist analysis is that this performance not only does not critique gender norms directly, but in fact is dependent upon them. It is achieved precisely by inhabiting a fissure within the terrain of femininity created by the interplay of gender norms with presumptions of childhood innocence.

Tomboy shows how the 'normal' innocence of childhood operates as an unmarked training in heteronormativity for girls, in line with Foucauldian theorising on the role innocence discourses can play as a covert and normalising subjectivation of girls. Yet Tomboy allows us to go further than this, suggesting a complexity that is not easily 
captured by Foucauldian accounts of 'normalisation' as the standardisation of subjectivities (see Link 2004). Foucault ([1976] 1968: 92-3) acknowledges that force relations that may generally support one another can also form 'disjunctures' at key intersections. However, where he attends closely to subjectivity, his focus is on the interplay of relations of power that produce the subject as an 'entire corpus of identity', the 'chimera of a substantial unity' ([1971] 1998: 375; [1974] 2006: 159). Renold's work, however, discerns how disjunctures between and within gender and age norms may be felt as competing imperatives. In doing so, she examines how the crosshatch of powerful norms of hyper-femininity and childhood innocence can organise the emergence of forms of young subjectivity which are not themselves normative (e.g. the 'sexualised girl', the tomboy, the successful but defeminised 'square girl').

Drawing on Renold, Tomboy can be understood as organised by the way in which the interleaving of gender norms and presumptions about childhood innocence may cause counter-normative possibilities to flare and become inhabitable. A tomboy femininity was permitted to Laure when it appeared to be merely 'playing "the boy"', since such childhood 'play' is not taken to express (hetero)sexuality for females. This differs from adolescence in which there is an 'increased pressure on girls to conform to heterosexualised femininities', such as that 'those girls who embodied it most thoroughly' tend to be 'the most powerful girl group' (Paechter 2010: 229; cf. Rysst 2010). This difference between 'child' and 'adolescent' femininities contrasts to the predicament of boys, for whom the 'sissy' is an abject form of subjectivity since masculinity is always already presumed to be meaningfully (hetero)sexual (see Kehily 2001; Davies 2008).

Thus the temporality and economy of expectations that organise young female subjectivation themselves provide a platform for a tomboy performance. Since gender identity is understood to be not yet attached to sexuality, Tomboy identifies how childhood innocence is permitted as a space for a degree of gender 'play' for girls - so long as this 'play' appears to leave their heteronormative future undisturbed. A tomboy performance depends upon the semantic polyvalence of childhood gender behaviour, such that a masculine performance can but need not tell directly of a masculine identity. However, this polyvalence is closed off when the 'truth' is discovered. When Laure's mother finds that 'you lied', she feels obliged to 'do what needs to be done'. She takes 
Laure to Lisa's house to ensure that their relationship is reorganised as one between 'girls'. Laure must be brought to identify herself as female rather than male, a difference in gendered subjectivity ultimately guaranteed by the coming of the school environment and its official and ongoing distinction between 'the boys' and 'the girls'.

\section{Hogan's Peter Pan}

The performance of Mickäel's masculinity is shown in Tomboy to require careful backstage work. Yet Butler's great insight in Gender Trouble was that heteronormative gender subjectivities are equally dependent upon such props and performative practices, but that these normative strategies are unmarked with the result that the consequent identities appear natural. She argues that 'the gendered body is performative suggests that it has no ontological status apart from the various acts which constitute its reality' and the appearance of an 'organised gender core' is 'an illusion discursively maintained for the purposes of the regulation of sexuality within the obligatory frame of reproductive heterosexuality’ (Butler 1990: 186). Jeanne tells us much the same in Tomboy: 'A young girl falls in love with a boy who plays rock-and-roll', she sings to her sibling as they both sit in the bath towards the start of the film, 'at the end of the schoolday, all the girls are wearing make-up.' No less than the tomboy performance, heternorms depend upon dress-up, folded into our desires.

Tomboy makes visible gender as a performative accomplishment. Yet its theoretical interest extends beyond this in also showing how gender norms intersect with age to place contradictory injunctions upon female subjects: to operate within both childhood innocence and aspirant compulsory heterosexuality. Moreover, the film shows how, in the very interstices of these norms, possibilities are opened to subjects for different kinds of performance - so long as essentialised identity-categories are left undisturbed. Considering P.J. Hogan's Peter Pan can help us advance these reflections, in exploring how normative emergent femininity too must manage these contradictory injunctions. The story of Peter Pan is a palimpsest of writings on innocence. This adds further complexity to any attempt to comment on the text, though Rose is quite correct that 'whenever innocence reappears on the cultural agenda, there is always something - I 
would suggest - to be learnt from Peter Pan' (Rose 1992: xi). Specifically, the story of Peter Pan on Hogan's retelling offers a dramatisation of how the contradictory injunctions upon female subjects are negotiated for a subject willing to accept some form of heteronormative reconciliation.

Hogan's film places Wendy and Peter in early adolescence and uses this device to emphasise and recombine those elements of Barrie's story which focus on heterosexual desire. A disjunctive synthesis is thereby produced, as a film about desire is constructed through a retelling of the paradigmatic story of childhood innocence. This disjuncture places Wendy firmly the protagonist of the tale, as the narrative arc of the film becomes centred on her becoming as a desiring subject. The interstices of gender and age norms that facilitated a tomboy performance of Sciamma's protagonist are dramatised as an entire world, Neverland, for Hogan's. This in turn produces a further disjuncture, as the Edwardian gender norms of the Darling home are set in contrast and continuity with the contemporary-feeling gender norms of Neverland. Hence, unlike in Barrie's story where a berth aboard the Jolly Roger is offered only to her brothers, in Hogan's film Wendy is flirtatiously urged by Hook into accepting the role of 'Red Handed Jill'. Jill is a 'brave swordsman' and 'storyteller', whom the Lost Boys think sounds 'quite fearsome'.

We meet Wendy in the Darling home, towering over her brothers as she tells them a story, inhabiting each character with her movements and speech, one by one: 'Cinderella flew through the air, far from all things ugly and ordinary. When she landed at the ball, she found herself most impertinently surrounded by pirates. There was Alf Mason, so ugly his mother sold him for a bottle of Muscat. Bill Jukes, every inch of him tattooed. And worst of them all, Hook, with eyes blue as forget-me-nots, save when he clawed your belly with the iron hook he has.' Inhabiting the character of Hook with a curled finger for a hook, and situating Wendy as Cinderella, her brother John interjects: 'Girlie, said Hook, we have come for ye glass slippers.' Wendy accepts identification as Cinderella, but contests the meaning of this subject-position, demanding to know, as Cinderella, 'who be you to order me about and call me girlie?' Unlike the protagonist of Tomboy, Wendy is willing to accept the ascription of being female, and does not contest that she might have the glass slippers that will lead her to her handsome prince. However, she questions the authority of her brother to interpellate her with the feminine diminutive, 'girlie'. 
Whereas the third adult in Barrie's version of the Darling household is Liza, a child-like maid, Hogan substitutes a new character: Aunt Millicent. This new character represents cultivation, and her function is to insist upon the training that is necessary in order to ensure that the unmarked gender norms of childhood are transferred into the marked gender norms of adult femininity. Aunt Millicent's role is to serve as a supplement, working to ensure that Wendy remains/becomes natural. In front of her parents and aunt, Wendy launches into a re-telling of the story of Hook and his pirates. Millicent stops her, exclaiming 'But, child, novelists are not highly thought of in good society. And there is nothing so difficult to marry as a novelist.' Mrs. Darling admonishes, 'but Aunt, Wendy is not yet thirteen.' Yet, 'quite as I expected', a 'hidden kiss' is discerned by Aunt Millicent, 'hidden in the right-hand corner' of Wendy's mouth. The 'hidden kiss', explains Aunt Millicent, 'is for the greatest adventure of all,' the encounter with 'the one the kiss belongs to'. Mr. Darling wonders at 'my Wendy, a woman'; Aunt Millicent qualifies, however, that Wendy is at present 'almost a woman': 'she must spend less time with her brothers, and more time with me. She must have... a young lady's room.' It is thus a combination of signs of the imagination to dream beyond expectations, together with adult perceptions of beginnings of puberty, that leads to recognition that Wendy must be trained for womanhood.

In Tomboy, the protagonist's status as a child meant that a masculine performance was taken merely as play, rather than an expression of the inner truth of the subject's sexual and gender identity. Hogan's Peter Pan dedicates itself to the articulation of heteronorms, safe in the knowledge that their staging in the adolescent becoming of a subject is not to be taken seriously. Neverland is an innocent 'detour' for Wendy's heteronormative femininity, but one that appears to safely leave her with a form of gendered subjectivity which was her natural possession all along. The foil for this project is Peter Pan, a figure defined by his refusal of becoming and his dedication to make-believe.

Hogan's Peter Pan was the first rendition of the story to have the character of Pan screen-acted by a male; yet gender as play re-emerges across the film as necessary support for the arc of its affect as a coming-of-age story. Hogan's Pan is not so much naturally innocent as wilfully so in the face of the available subject-positions of adult male. The film thereby addresses explicitly what Rose (1992: xii) has diagnosed as 
tacitly operating in previous versions, 'that Peter's innocence was protested in exact measure to the burden of repression which he had, from the outset, been expected to bear'. This culminates a history of images of Peter Pan over the past hundred years that have slowly aged the protagonist towards and then into adolescence (Munns 2009: 236). The fourteen-year-old actor (Jeremy Sumpter), who visibly undergoes a growthspurt in the course of filming, portrays a young man (Peter) who insists on being recognised as a masculine boy (Peter Pan). This insistence is situated by Peter Pan as an attempt to avoid the forms of desire characteristic of either of the two available adult male subject-positions: George Darling and Captain Hook (both played by Jason Isaacs).

Mr Darling is introduced by the narrator as 'a banker who knew the cost of everything, even a hug', which his wife explains as a consequence of having 'put away many dreams... for his family'. Darling's desires are not permitted to exceed the heteronormative family. By contrast, Hook embodies the ressentiment produced by Darling's sacrifices: the tears from his eye are described as a poisonous 'mixture of malice, jealousy and disappointment'. After all, as Nietzsche ([1887] 2007), I: §9, II: §23) tells us, ressentiment is a combination of imagination and poison. Vengeful desires are allowed to dominate all Hook's actions; he is named after his prosthesis, 'this fine hook for disembowelling and ripping throats', and, though in the meanwhile he dreams of his adversary, his world is literally a frozen wasteland in Pan's absence. This leaves him open to ridicule as leading an empty life, as there appears to be nothing to him but malice. Hook is taunted as 'old, alone, done for!' by Wendy and the lost boys as he is eaten by the crocodile.

On meeting Wendy, Peter explains that he left for Neverland when he 'heard my mother and father talking of what I was to be when I became a man'. The content of that proposed future is elaborated when Peter is offered the chance to leave Neverland: he demands to know 'Would they send me to school?' and 'then to an office?' It is thus in revolt at the available options for masculine adulthood that Peter claims that 'I want always to be a boy and have fun.' Wendy, however, recognises this as masquerade. 'You say so', she tells Peter, 'but I think it is your biggest pretend.' In this specific regard, Wendy is a more acute critic of Peter Pan than Kincaid (1992: 282), whose presumption that innocence means blankness leads him to suggest that 'Peter is resolutely boyish and is customarily played by females; it could as well be reversed. His position is not so 
much androgynous as beyond gender'. In fact, as I have previously argued, innocence is better regarded as the unmarked signs of aspirant heternormativity. Peter is open to performance by a woman precisely because his status as a child marks as mere play the ostentatious performance of his masculinity; by contrast the clearly teenage Sumpter depends upon his continual recourse to signs of a merely playful masculinity in order to be recognised as no older than a boy. The childhood of Hogan's Peter Pan relies on a performance of boyishness and irresponsibility that is primarily open to males.

Wendy makes use of Peter's 'biggest pretend', of always remaining a child, as a means of grappling with the gender expectations upon her own subjectivation. Girls, Peter tells us, 'are much too clever to fall out of their prams' in rejection of the normative injunctions on their future. Certainly Wendy does not reject growing up in toto but departs for Neverland only when, at thirteen, she is told that she already must engage in subjectivation according to conventional standards in order to hope for success, and happiness, in the Edwardian marriage market. In contrast to Barrie's ([1911] 2004: 65) story - in which Wendy accepts the role of mother to the Lost Boys with a resigned 'Oh dear... I feel that is just exactly what I am' - the criterion for motherhood in Neverland for Hogan's Lost Boys is 'do you tell stories?' Imagination is here situated as both the measure of domestic femininity, and also the site of deviation from convention - with each able to operate as such only because of the potential for the other. As a result, Wendy is able to try on and negotiate with the role of 'Mother Wendy': whilst the meaningfulness of these practices of the self are threatened by Peter's tremulous assertion that 'it's only make-believe isn't it?', this assertion also produces Neverland as a liminal space for such practices.

Whilst Neverland, with its contemporary gender norms, appears to be a space of gender freedom, it is in fact in covert continuity with and a roundabout means of serving the gender norms of Edwardian England. As Goffman (1972: 68-9) has discerned, drawing on insights from Kleinian psychoanalysis, 'the very means by which we hold off a part of reality can be the means by which we can bear introducing it', and hence 'an ocean voyage is fun not because it cuts us off from ordinary life but because, in being apparently cut off from ordinary life, we can afford to experience certain aspects of it.' It is thus at the very moment that Wendy knows that Pan 'needed a Wendy' and loves her in return that she can and must leave him to return to the project of achieving an 
Edwardian womanhood. It is both the contrasts and the continuities between gender power in the Darling house and Neverland that allow Wendy to use the latter as a site for weighing up and negotiating the demands of the former.

\section{Conclusion}

Commenting on Hogan's film, Kravey (2011: 8) alleges that Wendy 'exchanges her profound power as the teller of stories to deliver the fated kiss that saves Peter but dooms her to a life of heteronormative servitude in full Edwardian style... she has emotional range. But she trades so much for so little, and that ultimately makes me both sad and angry'. In the final scene of Peter Pan, Wendy is reconciled with her family and the narrator relates how she will tell stories of Peter to her children; in the final scene of Tomboy, the protagonist introduces herself again to Lisa, this time as 'Laure'. On one level, then, in both films the fates of gender power ultimately win out. The ostensive pattern runs: Darling household - Neverland - Darling household; Laure - Mickäel Laure. This, in turn, mirrors our captivation as viewers during each film, which extracts us from our lives for a time before then returning us to them again.

Yet both films suggest that the significance of the different possibilities of gender performance in late childhood/early adolescence are not simply gone; in doing so they resist the contempt with which the continuum of aged development would have us hold a passing phase. Wendy may return home to her family in the white night-dress of angelic childhood, accepting some form of heteronormative future. However, her nightdress has been overlaid with a leather baldric, holding a steel cutlass. Laure retains Mickäel's memories of footballing success, a deepened relationship with Jeanne, and possession of Mickäel's play-dough phallus in a heart-shaped box on the bedroom shelf. There are no certainties regarding whether or how these resources will be mobilised in the present or the future. Yet they do, by degrees, endure as the resources for assembling possibilities. Barrie ([1911] 2004: 146), for example, acknowledges that Neverland had a lasting impact on Wendy: 'she grew up of her own free will a day quicker than other girls.' Other possibilities may also be fabricated by the subject, perhaps to achieve something different from the ordinary course of events- what Walter Benjamin ([1940] 2003: 395) would call the use of the heterogeneity of the past to achieve a 'leap in the open air' in the present. 
For instance, relating sociological fieldwork experiences in a secondary school, Alicia Youngblood Jackson offers a description of Jesse, who engages in both weight-training and cheerleading. In the rally, the other cheerleaders 'spin around in their places, lift up the back of their skirts and expose the mascot paws emblazoned there. Three girls in the back row rotate their hips twice - as would a stripper on a pole. A few other girls shake their hips a little instead'. Jesse's 'muscled, differentiated body invading a short skirt and halter-top', however, is able to scaffold a different move again: surprising the audience, she does a standing backflip (Jackson 2010: 586). Thorne suggests that the tomboy strategy necessarily fails, as the girl is exiled back to a reviled subject-position. Yet Renold (2008: 144) found tomboys and former tomboys to have a 'more critical stance the sexual objectification of girls and women', and college-age students who report having been tomboys have been assessed as having higher than average selfesteem (see Volkom 2009).

Likewise, Tomboy and Peter Pan do not determine any one particular reading. Yet bringing them into conjunction with one another helps to identify what the protagonists and young women in contemporary society have in common: they each must grapple with young femininity as an 'impossible space' (Griffin 2004), in which subjects must signify both childhood innocence and heteronormative femininity or face the threat of a spoiled identity. The transience of the gender performance of the protagonists is therefore not a mark of its meaninglessness or failure, but the effect of what Renold calls 'the pushes and pulls of the simultaneous demand for compulsory innocence and compulsory heterosexuality'.

The interaction between age norms of childhood innocence and gender norms of heteronormative femininity motivate and facilitate Laure's tomboy performance: the use of masculine signifiers to circumvent gender exclusion is not perceived as problematic when understood as childhood play, as not yet speaking of the inner truth of the subject's sexual and gender identity. The norms Laure is escaping when Mickäel enters the woods, along with this means of escape, can be conceptualised as occurring upon a particular terrain of gender power, which enables and constrains possibilities (see Braidotti 2000). This contemporary terrain appears to be quite distinct from Edwardian gender norms, but Wendy's use of Neverland for negotiating and servicing heteronormativity, shows the continuities as well as the contrasts. The protagonists of 
Tomboy and Peter Pan, despite their differences, can thus be conceptualised, with Renold, as at the interstice between childhood innocence and compulsory heterosexuality: the plot of each film traces how the characters attempt to manoeuvre in the face of and using this contradiction.

\section{Bibliography:}

Barrie, J.M. ([1911] 2004) Peter and Wendy and Peter Pan in Kensington Gardens, London: Penguin

Benjamin, W. ([1940] 2003) 'Theses on the Concept of History' Walter Benjamin: Selected Writings, Volume 4, ed. Howard Eiland \& Michael W. Jennings, Cambridge, MA: Harvard University Press

Bettis, P.J. \& Adams, N.G. (2006) 'Short skirts and breast juts: cheerleading, eroticism and schools' Sex Education 6(2): 121-133.

Braidotti, R. 'Terratologies' in Deleuze and Feminist Theory, ed. Ian Buchanan \& Claire Colebrook, Edinburgh: Edinburgh University Press.

Butler, J. (1990) Bodies that Matter, London: Routledge.

Chambers, D., Tincknell, E \& van Loon, J. (2004) 'Peer regulation of teenage sexual identities' Gender and Education 16(3): 397-415

Dargis, M. (2011) 'A Summer of Freedoms in Boyhood' New York Times, 15th November

Davies, C. (2008) 'Becoming Sissy' in Judith Butler in Conversation: Analysing the Texts and Talk of Everyday Life, ed. Bronwyn Davies, (London: Routledge), pp.117-133

Deleuze, G. \& Guattari, F. ([1971] 1984) Anti-Oedipus, trans. Robert Hurley, NY: Continuum

Duschinsky 'Childhood Innocence: Essence, Education and Performativity' Textual Practice, early view.

Foucault, M. ([1971] 1998) 'Nietzsche, History, Genealogy' in Aesthetics: Essential Works, ed. James D. Faubion, London: Penguin.

Foucault, M. ([1975] 2003) The Abnormal, trans. Graham Burchell, NY: Picador.

Foucault, M. ([1976] 1978) The History of Sexuality Volume 1, trans. Robert Hurley, London: Penguin.

Goffman, E. (1972) Encounters, London: Penguin.

Griffin, C. (2005) "Impossible Spaces? Femininity as an Empty/Depopulated Category". Paper presented at the ESRC New Femininities Seminar Series, University of East London, December 2005.

Hey, V. (2009) 'The Girl in the Mirror: The Psychic Economy of Class in the Discourse of Girlhood Studies' Girlhood Studies, 2(2): 10-32;

Jackson, A.Y. (2010) 'Deleuze and the Girl' Qualitative Studies in Education, 23(5): 579-587

Kehily, M.J. (2001) 'Understanding heterosexualities: masculinities, embodiment and schooling' Men and Masculinities 4(2): 173-185

Kincaid, J. (1992) Child-Loving: The Erotic Child and Victorian Culture London: Routledge

Kravey, A.B. 'From Peanut Butter Jars to the Silver Screen' in Second Star to the Right: Peter Pan in the Popular Imagination, ed. Allison Kavey \& Lester D. Friedman, New Brunswick, New Jersey: Rutgers University Press.

Link, J. (2004) 'From the 'power of the norm' to 'flexible normalism': Considerations after Foucault', Cultural Critique, 57: 14-32

Mitchell, J. (2003) Siblings: Sex and Violence, Cambridge: Polity

Morgan, B.L. (1998) 'A Three Generational Study of Tomboy Behavior' Sex Roles 39(9): 787-800.

Munns, D. (2009) “'Gay, Innocent and Heartless”: Peter Pan and the Queering of Popular Culture' in Second Star to the Right: Peter Pan in the Popular Imagination, eds. Allison Kavey \& Lester D. Friedman, NY: Rutgers University Press.

Nietzsche, F. ([1887] 2007) On the Genealogy of Morality, trans. Carol Diethe, Cambridge: Cambridge University Press

Paechter, C.F. (2010) 'Tomboys and girly-girls: embodied femininities in primary schools' Discourse 
31(2): 221-235

Reay, D. (2001) 'Spice girls', 'nice girls', 'girlies' and 'tomboys': gender discourses, girls' cultures and femininities in the primary classroom, Gender \& Education, 13(2), $153-166$.

Renold, E. (1997) “All They've Got on Their Brains is Football.' Sport, Masculinity and the Gendered Practices of Playground Relations', Sport, Education and Society, 2:1, 5-23

Renold, E. (2001) 'Square-girls', Femininity and the Negotiation of Academic Success in the Primary School' British Educational Research Journal, 27(5): 577-588

Renold, E. (2002) 'Presumed innocence': (hetero)sexual, homophobic and heterosexist harassment amongst children in the primary school' Childhood, 9(4), 415-433

Renold, E. \& Allan, A. (2006) 'Bright and Beautiful: High achieving girls, ambivalent femininities, and the feminization of success in the primary school' Discourse 27(4): 457-473.

Renold, E. (2008) 'Queering masculinity: Re-Theorising Contemporary Tomboyism in the Schizoid Space of Innocent/Heterosexualized Young Femininities' Girlhood Studies 1(2): 129-151

Renold, E. (2009) 'Tomboys and Hegemonic Masculinity' in The Problem with Boys' Education, eds. Wayne Martino, Michael Kehler, Marcus B. Weaver-Hightower, London: Routledge, 2009

Renold, E. \& Ringrose, J. (2011) 'Schizoid subjectivities? Re-theorizing teen girls' sexual cultures in an era of 'sexualization' Journal of Sociology, 47(4): 389-409

Ringrose, J., Gill, R., Livingstone, S. \& Harvey, L. (2012) A Qualitative Study of Children, Young People and 'Sexting', London: NSPCC

Ringrose, J. and Renold, E. (2012) 'Teen girls, working-class femininity and resistance: retheorising fantasy and desire in educational contexts of heterosexualised violence' International Journal of Inclusive Education, 16(4): 461-477

Rose, J. (1992) The Case of Peter Pan, Or the Impossibility of Children's Fiction, Philadephila, PA: University of Pennsylvania Press 1992)

Rysst, M. (2010) "II am only 10 years old": Femininities, Clothing Fashion Codes and the Intergenerational Gap of Interpretation of Young Girls' Clothes' Childhood 17(1): 76-93.

Sciamma, C. (2011) 'Interview with the Director', available at: http://www.originalplumbing.com/2011/12/05/celine-sciammas-tomboy-an-interview-withthe-director/

Thorne, B. (1993) Gender Play, London: Open University Press

Volkom, M. (2009) 'The effects of childhood tomboyism and family experiences on the self-esteem of college females' College Student Journal, 43(3).

Wilson, E. (2003) Cinema's Missing Children, NY: Columbia University Press. 